\title{
Hepatoprotective effects of marjoram (Origanum marjorana L.) on oxidative stress against Carbon-Tetrachloride-Induced Toxicity in Rats
}

\author{
Naglaa, H. M. Hassanen \\ Special Food and Nutrition Department, Food Technology Research Institute, Agricultural \\ Researches Center, Giza , Egypt
}

\begin{abstract}
Liver injury induced by viruses, toxic chemicals, certain drugs and environmental pollutants, has been on the increase for the past few decades and recognized as a toxicological problem. Carbon tetrachloride is a xenobiotic that produces hepatotoxicity. Marjoram is popular herb for its beneficial or therapeutic health effect. The present study was carried out to investigate the hepatoprotective effect of marjoram against carbon tetrachloride intoxication in rats compared with drug $(25 \mathrm{mg} / \mathrm{kg}$ diet). Albino rats weighing $200 \pm 5 \mathrm{~g}$ were subjected to hepatotoxicity by injection of $(0.1$ $\mathrm{ml} / 100 \mathrm{~g}$ b.wt.) $\mathrm{Ccl}_{4}$ twice weekly for two weeks intraperitoneally except the control group. Rats were divided into 7 groups $(n=6)$ of non- hepatotoxicity, non- hepatotoxicity and treated, hepatotoxicity non-treated and hepatotoxicity treated with drug, marjoram powder or their essential oil. After 4 weeks the rats fed with spice or their essential oil supplied to hepatotoxic rats had significantly decreased levels of glucose. The treatment also resulted in a significant improvement in lipid profile, liver function and kidney function. However, a significant increase in the activities of superoxide dismutase (SOD), catalase (CAT), glutathione peroxidase (GSH-Px) and glutathione reduced (GSH) were observed in blood of hepatotoxicified rats treated with marjoram. The treated groups showed a significant decrement in thiobarbituric acid reactive substances (MDA) in serum. Since the study of induction of the redox enzymes is considered to be a reliable marker for evaluating the antiperoxidative efficacy of the spices, these findings suggest a possible antiperoxidative role derived from such essential oil. Treatment with spices marjoram or their essential oil reduced the histopathological liver, kidney, heart and spleen abnormalities associated with hepatotoxicity. Moreover to the anti hepatotoxicity effect it possess antioxidant potential that may be used for therapeutic purposes. The present study showed that marjoram was able to prevent or reduce the severity of carbon tetrachloride - induced liver injury.
\end{abstract}

Key words: Carbon tetrachloride, Marjoram essential oil , Hepatotoprotective, Glucose, Cholesterol , Triglycerides., liver Function, kidney Function ,SOD, CAT, GSH-Px, GSH, MDA, Histopathological, liver, kidney, heart, spleen.

\section{Introduction}

The liver plays an important role in detoxification of foreign substances, in the secretion of bile for digestion, and in the metabolic functions of various nutrients including carbohydrates, proteins, and fats Saleem et al., (2010). Hence, chronic liver injury has serious medical consequences. A common chronic disease known as liver fibrosis may lead to end-stage liver cirrhosis and liver cancer Ao et al ., (2009). Excessive consumptions of alcohol and viral infections are the most common risk factors for liver diseases in developed countries, while environmental pollution, hepatic viruses, parasitic infections, and chemotherapeutics are the main factors known to cause hepatic damage in developing countries Alshawsh et al ., (2011). In spite of medical advances, conventional medicinal approaches have undesirable adverse 
effects, lack efficiency, and are costly, especially for patients in developing countries Stickel and Schuppan (2007). Elimination of risk factors and alleviation of liver fibrosis are the most common approaches to prevent liver deterioration Brenner et al., (2000). Therefore, there is an urgent need for safe alternative therapeutics to treat liver pathology. Many natural products are being targeted for liver disease prevention and/or treatment Saleem et al., (2010). In recent years, sweet marjoram (Origanum majorana L.), a member of the Lamiaceae family, is an aromatic plant; of great economic and industrial importance. It is known since antiquity for its therapeutic properties (Bâatour et al., 2011). Notably among all Lamiaceae species, it is used in gastronomy for its spicy herbaceous notes (El- Ashmawy et al., 2007), especially in the Mediterranean culinary delights. Volatile extract of marjoram is used in pharmacology, medicine, clinical microbiology, pathology and food preservation (Barbosa et al., 2009). The essential oil obtained from the flowering heads of marjoram has aromatic smell and contain high percentage of polyphenols and monoterpenes which are established antioxidants (EL Bushuty and Shanshan, 2012)..Marjoram essential oil could protect liver and kidney damage, and lead acetate injury (Abd El-Ghany and El-Metwally, 2010). The aim of this study was to explore the hepatoprotective effect of sweet marjoram (Origanum majorana L.), against Carbon-Tetrachloride-Induced Liver Injury in Rats.

\section{Materials and Methods}

Spice sweet Marjoram (Origanum marjorana L.)was purchased from Pharmaceutical Science Laboratory, National Research Centre, Giza, Egypt .Silymarin was purchased from pharmacy . Carbon tetrachloride ( $\left.\mathrm{Ccl}_{4}\right)$ : $(99.9$ purity) was purchased from Sigma Chemical Company. Ccl4 (1 ml/kg b.wt. as 1:1(v/v) mixture with liquid paraffin twice/week, intraperitoneally according to Roy et al., (2006) .

Extraction of essential oils from spices: The essential oil of Marjoram (Origanum marjorana L.) spice was obtained by water distillation using a (Clevenger-type apparatus) for 4 hours. The separated volatile oil was dried over anhydrous sodium sulphate before holding glass bottles at $-20^{\circ} \mathrm{C}$, according to Guenther (1961).

Animals: Forty two male Albino rats, average weight of $200 \pm 5 \mathrm{~g}$. raised in the animal house of the Ophthalmology Research Institute, Giza, Egypt, were used in the present study. The rats were kept under normal healthy laboratory condition; temperature was adjusted at $25 \pm 2{ }^{\circ} \mathrm{C}$ and 12 hour light - dark. Animals were adapted on free access of water, and fed for one week basal diet before the initiation of the experiment .

Composition of the basal diet (g/kg) : Casein, $10 \%$;cellulose,5\%;corn oil, $10 \%$; corn starch ,70\%; salt mixture, $4 \%$ and vitamin mixture ,1\% according to Lane Peter and Pearson 1971, Hegsted et al.,1941 and Campbell, 1963 , respectively.

Experimental design: Seven equal groups each of six rats were housed in wire cages in a room temperature maintained at $25^{\circ} \mathrm{C} \pm 2$ and kept under normal healthy conditions. All rats body weights and food consumption were recorded every week for determination body weight gain. Rats of the first group (MI) kept as control negative (normal control) and fed on basal ration. Rats of the second group (M2) were used as positive control, fed on basal ration and was injected intraperitoneally by $\left(0.1 \mathrm{ml} / 100 \mathrm{~g} \mathrm{~b}\right.$.wt.) $\mathrm{Ccl}_{4}$ twice weekly for two weeks. Rats of the third group (M3) fed on basal ration mixed with silymarin at concentration $(25 \mathrm{mg} / \mathrm{kg}$ diet $)$ for 30 successive days and at the same time injected intraperitoneally by $\left(0.1 \mathrm{ml} / 100 \mathrm{~g} \mathrm{~b} . w \mathrm{t}\right.$.) $\mathrm{Ccl}_{4}$ twice week for two weeks. Rats of the fourth group (M4) fed on basal ration mixed with essential oil marjoram (Origanum marjorana L.)at concentration $300 \mathrm{mg} / \mathrm{kg}$ for 30 successive days. The fifth Group (M5) fed on basal ration mixed with $10 \%$ powder marjoram for 30 successive days. The sixth Group (M6) were fed on basal ration mixed with essential oil marjoram at concentration $300 \mathrm{mg} / \mathrm{kg}$ for 30 successive days and at the same time injected intraperitoneally by $\left(0.1 \mathrm{ml} / 100 \mathrm{~g} \mathrm{b.wt}\right.$.) $\mathrm{Ccl}_{4}$ twice weekly for two weeks . Rats of seventh group (M7) were 


\section{Egypt. J. of Nutrition and Health Vol. 7 No. 1 (2012)}

fed on basal ration mixed with powder marjoram at concentration $10 \%$ for 30 successive days and at the same time injected intraperitoneally by $\left(0.1 \mathrm{ml} / 100 \mathrm{~g} \mathrm{~b}\right.$.wt.) $\mathrm{Ccl}_{4}$ twice weekly for two weeks.

Growth of rats: The gain in the body weights was calculated by : Body weight gain = final weight- initial weight in grams.

Biochemical assay: At the end of the experimental period, blood samples were collected from the eye plexuses of animals on ice. Each sample was collected into both heparinized tube to obtain the plasma and into a dry clean centrifuge glass tube without any coagulation to prepare serum. Blood was left for $15 \mathrm{~min}$ at room temperature, then the tubes were centrifuged for $15 \mathrm{~min}$ at $3000 \mathrm{rpm}$ and the clean supernatant serum was kept frozen at $-20^{\circ} \mathrm{C}$ until the time of analysis. Serum glucose was determined by Trinder,1969. Total cholesterol (TC.), high density lipoprotein (HDL), low density lipoprotein (LDL), VLDL- cholesterol and triglycerides (TG.) were determined by using the methods described by Waston (1960), Assmann (1979), Wieland and Seidel (1983), Wallach (1992) and Fossati and Prencipe (1982), respectively. Liver function: Alanine aminotransferase (ALT) and aspartate aminotransferase (AST) activities were assayed by the method of Bergmeyer and Harder, 1986. Alkaline phosphatase (ALP) activity was measured at $405 \mathrm{~nm}$ by the formation of paranitrophenol from para-nitrophenylphosphate as a substrate using the method of Varley et al., 1980. Kidney function : Creatinine was measured using he method of Henry (1974), Urea was measured using the method of Fawcett and Scott (1960). The activity of lipid peroxidation level (Malondialdehyde, MDA) was determined in serum by the colorimetric method described by (Meltzer et al., 1997). Superoxide dismutase (SOD), catalase(CAT), glutathione peroxides (GSPx) and glutathione reduced (GSH) were measured calorimetrically in erythrocyte according to the method of Nishikimi et al., (1972), Aebi (1984), Rotruck et al., (1973) and Ellman (1959), respectively .

Histopathological examination: Sample from the liver, heart, kidneys and spleen were collected from rats in all groups at the end of experiments (30 days), fixed in 10\% neutral buffered formalin, dehydrated in alcohol, cleared in xylol and embedded in paraffin. $4 \mu$ thick sections were prepared and stained with Hematoxylene and Eosin (Yoon et al., 2001).

Statistical analysis: The obtained results were subjected to statistical analysis using the standard analysis of variance as outlined by Snedecor and Cochran (1980).

\section{Results and discussion}

The present study was carried out to elucidate the chemical composition of essential oil, nutritional and protective effect of marjoram (Origanum marjorana L.)in normal and on carbon tetrachloride $\left(\mathrm{Ccl}_{4}\right)$ induced cytogenicity and liver injury, using powder and essential oil marjoram for 30 days in male albino rats. The tested parameters were chemical constituents and histopathological examination of liver, heart, kidney and spleen in normal rats and rats injected with $\mathrm{Ccl}_{4}$. Their effects and constituents are registered in tables and Photographs.

Chemical composition of essential oil: Essential oil percentage of marjoram spice was $1.54 \%$. The obtained data are in harmony with the findings of Lis et al., (2007). The chemical constituents of origanum marjorana essential oil are tabulated in Table (1). From these results, it could be indicated that, 24 components were isolated from origanum marjorana essential oil. Sixteen component were identified and classified into 8 chemical categories namely, monocyclic terpenes $(28.88 \%)$, bicyclic terpenes $(9.97 \%)$, aliphatic hydrocarbons $(1.22 \%)$, aromatic hydrocarbons $(13.11 \%)$, alcohols $(40.30 \%)$, esters $(0.23 \%)$, phenols $(0.43 \%)$ and bicyclic sesquiterpene $(3.44 \%)$. These identified compounds accounted for $97.58 \%$ of the composition of origanum marjorana essential oil. The remainder portion, $2.42 \%$, representing 8 unknown constituents. The first chemical group in Table (1) origanum marjorana essential oil was monocyclic terpenes which consisted of 4 compounds namely, Limonene $(3.09 \%)$; phellandrene $(0.64 \%)$, $\mathrm{y}$-terpinine 
(15.70\%) and a-terpinine (9.45\%). These compounds were reported as constituents of marjoram essential oil by Freire et al., 2011 and Baâtour et al.,(2012c). The second recorded chemical group was bicyclic terpenes which consisted of 4 compounds namely; a-pinene (1.12\%), Camphene $(1.41 \%)$, sabinene $(6.77 \%)$ and $\beta$-pinene $(0.67 \%)$. These compounds were reported as constituents of marjoram essential oil by Lis et al., (2007). The third identified chemical group was aliphatic hydrocarbons which consisted of one compound namely; $\beta$-myercene (1.22\%). This compound was reported as constituent of origanum marjorana essential oil by Freire et al., (2011). The fourth identified chemical group was aromatic hydrocarbons which consisted of one compound namely; P-cymene $(13.11 \%)$. This compound was reported as constituent of origanum marjorana essential oil by Baâtour et al., (2012c). The fifth identified chemical group was alcohols which consisted of three compounds namely; linalool (2.64\%), terpene-4-ol (34.46\%) and a- terpineol $(3.20 \%)$. Terpene-4-ol this compound was reported as the major constituent of origanum marjorana essential oil by Freire et al., 2011. The six chemical group recorded and identified in origanum marjorana essential oil was esters, one compound was found in it namely; linalyl acetate $(0.23 \%)$. The seventh chemical group recorded and identified in origanum marjorana essential oil was phenols which consisted of one compound namely; namely; thymol $(0.43 \%)$. The eighth chemical group was bicyclic sesquiterpene which consisted of one compound namely; $\beta$-caryophyllene ( $3.44 \%)$.

Effect of origanum marjorana powder and their essential oil on body and organ of experimental rats injected with $\mathrm{Ccl}_{4}$ : Data presented in Table (2) showed that initial body weights did not significantly differ among the groups and effect of feeding on ration mixed with powder and essential oil marjoram at $10 \%$ and $300 \mathrm{mg} / \mathrm{kg} \mathrm{deit,}$ respectively for 30 successive days with or without injection of carbon tetra-chloride ( twice / week for two weeks ) on body weight gain are recorded in the same Table. Body weight gain was significantly increased in rats feed on ration mixed with powder and essential oil marjoram when compared with other groups,these findings correlated with those obtained by EL Bushuty and Shanshan (2012) while the group injected $\mathrm{CCl}_{4}$ showed significant decrease in body weight gain (Adewole et al ., 2007). Moreover, the groups fed on powder and essential oil marjoram with injection of $\mathrm{CCl}_{4}$ improved the body weight gain which significantly increased when compared with the group injected with $\mathrm{CCl}_{4}$. The beneficial effect of antioxidant administration against $\mathrm{CCl}_{4}$ poisoning with respect to body weight observed in the present study confirms previous results obtained by Aneja et al., (2005) who concluded that feeding rats with antioxidants could play an important role as a prophylactic against the toxic effects of $\mathrm{Ccl}_{4}$. Baâtour et al., (2012a) found that marjoram contain several compound such as phenolic components and flavonoids to be responsible for this antioxidant effect. Moreover, there were no significant differences in liver, kidney, heart and spleen relative organs weight in rats fed on ration mixed with powder and essential oil marjoram (with or without injection of carbon tetra-chloride ) compared with control(M1) group. On the contrary, there were increased significant differences in liver, kidney, heart and spleen relative organs weight in rats fed on silymarin and rats injected $\mathrm{Ccl}_{4}$ (M2) in Table (2). Lee et al., (2007), Adewole et al .,(2007) and Tsai et al .,(2008) reported that relative organs weight were significantly increased after injection with $\mathrm{Ccl}_{4}$. 
Table (1):

Chemical components of origanum marjorana essential oils fractionated and identified by GC/Mass technique.

\begin{tabular}{|c|c|}
\hline \multirow{2}{*}{ Chemical compounds } & Area $\%$ \\
\hline & Rrignum mariomn \\
\hline \multicolumn{2}{|l|}{ 1-Monocyclic terpenes: } \\
\hline Limonene & 3.09 \\
\hline a-Phellandrene & 0.64 \\
\hline y-terpinene & 15.70 \\
\hline a-terpinene & 9.45 \\
\hline Total : & 28.88 \\
\hline \multicolumn{2}{|l|}{ 2-Bi cyclic terpenes: } \\
\hline a-pinene & 1.12 \\
\hline Camphene & 1.41 \\
\hline Sabinene & 6.77 \\
\hline$\beta$-pinene & 0.67 \\
\hline Total : & 9.97 \\
\hline \multicolumn{2}{|l|}{ 3-Aliphatic hydrocarbons: } \\
\hline$\beta$-Myercene & 1.22 \\
\hline Total : & 1.22 \\
\hline \multicolumn{2}{|l|}{ 4-Aromatic hydrocarbons: } \\
\hline p-cymene & 13.11 \\
\hline Total: & 13.11 \\
\hline \multicolumn{2}{|l|}{ 5- alcohols: } \\
\hline Linalool & 2.64 \\
\hline Terpene-4-ol & 34.46 \\
\hline a-Terpineol & 3.20 \\
\hline Total: & 40.30 \\
\hline \multicolumn{2}{|l|}{ 6- Esters: } \\
\hline Linalyl acetate & 0.23 \\
\hline Total: & 0.23 \\
\hline \multicolumn{2}{|l|}{ 7-Phenols: } \\
\hline Thymol & 0.43 \\
\hline Total: & 0.43 \\
\hline \multicolumn{2}{|l|}{ 8- Bi cyclic sesquiterpene: } \\
\hline$\beta$-Caryophyllen & 3.44 \\
\hline Total: & 3.44 \\
\hline 9-Unknown: & 2.42 \\
\hline
\end{tabular}


Table (2):

Effect of origanum marjorana powder and their essential oil on body and organ of experimental rats injected with $\mathrm{Ccl}_{4}$.

\begin{tabular}{|c|c|c|c|c|c|c|c|}
\hline Treatments & $\begin{array}{l}\text { Initial } \\
\text { (g) }\end{array}$ & $\begin{array}{l}\text { Final } \\
(\mathrm{g})\end{array}$ & Weight gain & $\begin{array}{c}\text { Liver } \\
\%\end{array}$ & $\begin{array}{c}\text { Heart } \\
\%\end{array}$ & $\begin{array}{c}\text { Kidney } \\
\%\end{array}$ & $\begin{array}{c}\text { Spleen } \\
\%\end{array}$ \\
\hline $\begin{array}{l}\text { M1(Control } \\
\text { normal) }\end{array}$ & $199.6^{\mathrm{a}} \pm 0.150$ & $250.4^{e} \pm 1.900$ & $50.75^{e} \pm 2.050$ & $2.230^{c} \pm 0.230$ & $0.34^{\mathrm{bc}} \pm 0.02$ & $0.547^{c} \pm 0.007$ & $0.272^{c} \pm 0.002$ \\
\hline $\mathrm{M} 2$ (control $\mathrm{Ccl}_{4}$ ) & $199.3^{\mathrm{a}} \pm 1.420$ & $210.6^{9} \pm 2.950$ & $11.22^{9} \pm 1.530$ & $4.810^{a} \pm 0.810$ & $0.46^{a} \pm 0.03$ & $0.978^{a} \pm 0.078$ & $0.621^{a} \pm 0.021$ \\
\hline $\begin{array}{l}\mathrm{M} 3 \text { (Silymarin + } \\
\mathrm{Ccl}_{4} \text { ) }\end{array}$ & $200.4^{a} \pm 0.402$ & $226.2^{\prime} \pm 1.960$ & $25.81^{\prime} \pm 1.705$ & $3.310^{b} \pm 1.078$ & $0.39^{b} \pm 0.01$ & $0.8157^{b} \pm 0.014$ & $0.546^{b} \pm 0.006$ \\
\hline $\begin{array}{l}\text { M4 (marjoram } \\
\text { essential oil ) }\end{array}$ & $200.4^{a} \pm 0.810$ & $288.4^{a} \pm 0.950$ & $87.94^{a} \pm 0.140$ & $2.150^{c} \pm 0.150$ & $0.31^{c} \pm 0.012$ & $0.562^{c} \pm 0.062$ & $0.2817^{c} \pm 0.003$ \\
\hline $\begin{array}{l}\text { M5(marjoram } \\
\text { powder) }\end{array}$ & $199.8^{\mathrm{a}} \pm 3.690$ & $278.6^{b} \pm 0.600$ & $78.78^{b} \pm 3.090$ & $2.260^{c} \pm 0.260$ & $0.33^{c} \pm 0.015$ & $0.554^{c} \pm 0.054$ & $0.271^{c} \pm 0.001$ \\
\hline $\begin{array}{l}\text { M6 (marjoram } \\
\text { essential oil }+\mathrm{Ccl}_{4} \text { ) }\end{array}$ & $199.7^{\mathrm{a}} \pm 0.460$ & $261.3^{\mathrm{C}} \pm 2.140$ & $61.61^{c} \pm 2.600$ & $2.630^{c} \pm 0.430$ & $0.35^{c} \pm 0.02$ & $0.564^{c} \pm 0.014$ & $0.2867^{c} \pm 0.012$ \\
\hline $\begin{array}{l}\text { M7 (marjoram } \\
\left.\text { powder }+\mathrm{Ccl}_{4}\right)\end{array}$ & $200.8^{\mathrm{a}} \pm 2.660$ & $257: 1^{d} \pm 2.390$ & $56.27^{\mathrm{d}} \pm 0.270$ & $2.710^{c} \pm 0.710$ & $0.33^{c} \pm 0.030$ & $0.595^{c} \pm 0.034$ & $0.2807^{c} \pm 0.020$ \\
\hline LSD & 2.720 & 1.378 & 3.127 & 0.9175 & 0.05626 & 0.056 & 0.0562 \\
\hline
\end{tabular}

- Means, within the same column, followed by the same letter are not significantly different at $<0.05$.

- Means are followed by the corresponding standard deviation

Effect of origanum marjorana powder and their essential oil on serum glucose and lipid profile levels in experimental rats injected with $\mathrm{Ccl}_{4}$ : Table (3) displays the levels of serum glucose in normal and experimental animals. The data revealed a significantly increase $(197.22 \%)$ in blood glucose in rats injected with $\mathrm{Ccl}_{4} \mathrm{Compared} \mathrm{to}$ normal rats. Meanwhile, there was no change in concentrations of serum glucose of rats given powder and essential oil marjoram, but glucose concentrations were significantly higher in the serum of rats injected with $\mathrm{Ccl}_{4}$. Rats fed on ration mixed with silymarin and (powder and essential oil) marjoram with injected $\mathrm{Ccl}_{4}$ showed significantly decrease in glucose concentration than other groups. Total cholesterol and triglycerides concentrations did not induce changes in the serum of rats given powder and essential oil marjoram than the control (M1) group. The oxidation stress (injected with $\mathrm{Ccl}_{4}$ ) significantly increased $(107.87,519.99,108.95$ and $108.98 \%)$, respectively in serum total cholesterol (TC), low density lipoprotein (LDL-C), very low density lipoprotein cholesterol (VLDL-C) and triglycerides(TG).While HDL- cholesterol was significantly decreased (30.76\%), as shown in Table ( 3 ). Administration of the tested antioxidants improved or returned these values to the normal ones EL Bushuty and Shanshan (2012) reported that TC and TG were significantly decreased after feeding rats with marjoram .Meanwhile, Ozturk et al .,(2012) who reported that rats fed silymarin with injected $\mathrm{CCl}_{4}$ had significant decrease in glucose level. 
Table (3):

Effect of origanum marjorana powder and their essential oil on serum glucose, total cholesterol, high density lipoprotein (HDL) and triglycerides levels in experimental rats injected with $\mathrm{Ccl}_{4}$.

\begin{tabular}{|c|c|c|c|c|c|c|}
\hline Treatments & $\begin{array}{l}\text { Glucose } \\
\text { (mg/dl) }\end{array}$ & $\begin{array}{c}\mathrm{TC} \\
(\mathrm{mg} / \mathrm{dl})\end{array}$ & $\begin{array}{l}\text { HDL-C } \\
(\mathrm{mg} / \mathrm{dl})\end{array}$ & $\begin{array}{l}\text { LDL-C } \\
(\mathrm{mg} / \mathrm{dl})\end{array}$ & $\begin{array}{l}\text { VLD-C } \\
(\mathrm{mg} / \mathrm{dl})\end{array}$ & $\begin{array}{c}\text { T.G } \\
(\mathrm{mg} / \mathrm{dl})\end{array}$ \\
\hline M1(Control normal) & $81.22^{e} \pm 0.220$ & $78.51^{\mathrm{e}} \pm 0.510$ & $48.25^{a} \pm 1.150$ & $16.21^{d} \pm 1.138$ & $13.86^{e} \pm 0.260$ & $69.29^{e} \pm 1.290$ \\
\hline $\mathrm{M} 2$ (control $\mathrm{Ccl}_{4}$ ) & $241.40^{\mathrm{a}} \pm 0.808$ & $163.20^{\mathrm{a}} \pm 2.200$ & $33.41^{d} \pm 0.346$ & $100.50^{a} \pm 1.226$ & $28.96^{a} \pm 0.185$ & $144.80^{\mathrm{a}} \pm 0.924$ \\
\hline $\begin{array}{l}\text { M3(Silymarin + } \\
\left.\mathrm{Ccl}_{4}\right)\end{array}$ & $139.30^{b} \pm 2.173$ & $103.10^{b} \pm 2.150$ & $40.14^{b} \pm 1.640$ & $40.48^{b} \pm 0.075$ & $22.43^{b} \pm 0.435$ & $112.10^{b} \pm 2.150$ \\
\hline $\begin{array}{l}\text { M4 (marjoram } \\
\text { essential oil ) }\end{array}$ & $81.21^{e} \pm 0.187$ & $78.07^{e} \pm 0.330$ & $48.20^{a} \pm 0.200$ & $15.66^{\mathrm{d}} \pm 0.471$ & $13.82^{\mathrm{e}} \pm 0.076$ & $69.08^{e} \pm 0.380$ \\
\hline $\begin{array}{l}\text { M5(marjoram } \\
\text { powder) }\end{array}$ & $81.50^{\circ} \pm 0.178$ & $78.70^{e} \pm 0.917$ & $48.22^{a} \pm 0.293$ & $16.39^{d} \pm 0.983$ & $13.79^{\mathrm{e}} \pm 0.172$ & $68.96^{e} \pm 0.855$ \\
\hline $\begin{array}{l}\text { M6 (marjoram } \\
\text { essential oil }+\mathrm{Ccl}_{4} \text { ) }\end{array}$ & $113.20^{\mathrm{d}} \pm 1.168$ & $90.75^{d} \pm 1.250$ & $39.64^{b} \pm 1.640$ & $31.52^{c} \pm 0.552$ & $19.44^{\mathrm{d}} \pm 0.240$ & $97.19^{d} \pm 1.190$ \\
\hline $\begin{array}{l}\text { M7 (marjoram } \\
\text { powder }+\mathrm{Ccl}_{4} \text { ) }\end{array}$ & $120.80^{C} \pm 1.266$ & $97.53^{c} \pm 1.600$ & $35.36^{c} \pm 2.360$ & $41.38^{b} \pm 0.992$ & $20.53^{c} \pm 0.330$ & $102.60^{c} \pm 1.650$ \\
\hline LSD & 2.072 & 1.550 & 1.776 & 2.088 & 0.2516 & 1.235 \\
\hline
\end{tabular}

- Means, within the same column, followed by the same letter are not significantly different at $<0.05$.

- Means are followed by the corresponding standard deviation

Effect of origanum marjorana powder and their essential oil on the liver functions and kidney functions levels in experimental rats injected with $\mathrm{Ccl}_{4}$ : The obtained results showed that feeding on ration mixed with powder and essential oil marjoram ( $10 \%$ and $300 \mathrm{mg} / \mathrm{kg}$ diet) did not induce changes in serum AST, ALT and ALP when compared with control M1 group. Administration of M2 ( injected with $\mathrm{Ccl}_{4}$ ) produced significant adverse effects on the liver functions and kidney functions of the rats, which is evidenced by a significant increase in the activities of ALT, AST and ALP enzymes and kidney functions (creatinine and urea) as compared with normal in Table (4). Injection of rats with $\mathrm{Ccl}_{4}$ led to significant increase of both AST and ALT enzymes, as compared to control group (M1). It is believed that the most accepted hypothesis of hepatotoxicity for $\mathrm{Ccl}_{4}$ is the bioactivation of $\mathrm{Ccl}_{4}$ molecules to the trichloromethyl toxic free radical by certain is coenzymes of cytochrome $\mathrm{P}-450$. When $\mathrm{Ccl}_{3}$ is formed, it leads to lipid peroxidation of the polyunsaturated fatty acid in cell membranes, break down of membrane - structure and leading to the release of microsomal corboxyal esterase and other enzymes, such as amino transferases into the extra cellular compartments including serum (Wong et al., 1998 ). These results agree with previous studies of Adewole et al .,(2007) . The mechanism of elevated serum levels of urea and creatinine were explained by Venkatanarayana et al., (2012), who found that antioxidant enzymes activities (GSH-Px, Catalase and SOD) levels were decreased significantly following injected $\mathrm{Ccl}_{4}$ exposure. Treatment of rats (injected with $\mathrm{CCl}_{4}$ ) with silymarin (M3) and (with marjoram powder (M5) and essential oil (M4)) exhibited improvement in liver and kidney functions with better results compared to M2 group (injected with $\mathrm{CCl}_{4}$ ) rats. These results may be attributed to the presence of antioxidants of marjoram which had important beneficial effects on the liver regeneration Baâtour et al., (2012a).

Ozturk et al .,(2012) reported that rats fed with silymarin with injected $\mathrm{Ccl}_{4}$ were significantly decreased in liver function and kidney functions . 
Table (4):

Effect of origanum marjorana powder and their essential oil on the liver functions and kidney functions levels in experimental rats injected with $\mathrm{Ccl}_{4}$.

\begin{tabular}{|c|c|c|c|c|c|}
\hline \multirow[b]{2}{*}{ Treatments } & \multicolumn{3}{|c|}{ Liver functions } & \multicolumn{2}{|c|}{ Kidney functions } \\
\hline & $\begin{array}{l}\text { ALT } \\
(\mathrm{U} / \mathrm{L})\end{array}$ & $\begin{array}{l}\text { AST } \\
(\mathrm{U} / \mathrm{L})\end{array}$ & $\begin{array}{l}\text { ALP } \\
(U / L)\end{array}$ & $\begin{array}{l}\text { Creatinine } \\
\text { (mg/dl) }\end{array}$ & $\begin{array}{c}\text { Urea } \\
(\mathrm{mg} / \mathrm{dl})\end{array}$ \\
\hline M1(Control normal) & $24.05^{\mathrm{e}} \pm 1.496$ & $28.47^{e} \pm 0.470$ & $68.35^{e} \pm 0.350$ & $0.065^{\mathrm{e}} \pm 0.005$ & $22.28^{\mathrm{e}} \pm 1.280$ \\
\hline M2 (control $\mathrm{Ccl}_{4}$ ) & $69.25^{\mathrm{a}} \pm 1.250$ & $87.69^{a} \pm 2.690$ & $294.20^{\mathrm{a}} \pm 4.190$ & $1.660^{\mathrm{a}} \pm 0.006$ & $64.85^{a} \pm 2.850$ \\
\hline $\mathrm{M} 3\left(\right.$ Silymarin $\left.+\mathrm{Ccl}_{4}\right)$ & $47.18^{b} \pm 2.180$ & $59.22^{\mathrm{b}} \pm 1.220$ & $231.70^{b} \pm 1.660$ & $1.410^{b} \pm 0.110$ & $57.23^{\mathrm{b}} \pm 1.230$ \\
\hline $\begin{array}{l}\text { M4 (marjoram essential } \\
\text { oil ) }\end{array}$ & $23.91^{\mathrm{e}} \pm 3.910$ & $28.68^{e} \pm 3.680$ & $68.57^{\mathrm{e}} \pm 3.570$ & $0.086^{e} \pm 0.024$ & $22.41^{\mathrm{e}} \pm 2.410$ \\
\hline M5(marjoram powder) & $24.11^{e} \pm 1.110$ & $28.84^{\mathrm{e}} \pm 1.840$ & $68.63^{e} \pm 2.990$ & $0.081^{\mathrm{e}} \pm 0.006$ & $22.66^{e} \pm 1.660$ \\
\hline $\begin{array}{l}\text { M6 (marjoram essential } \\
\left.\text { oil }+\mathrm{CCl}_{4}\right)\end{array}$ & $30.16^{d} \pm 2.085$ & $45.70^{d} \pm 1.892$ & $109.30^{d} \pm 2.250$ & $0.996^{\mathrm{d}} \pm 0.109$ & $32.86^{\mathrm{d}} \pm 0.860$ \\
\hline $\begin{array}{l}\text { M7 (marjoram powder + } \\
\mathrm{Ccl}_{4} \text { ) }\end{array}$ & $35.00^{c} \pm 4.770$ & $53.14^{c} \pm 3.140$ & $145.20^{c} \pm 5.210$ & $1.270^{c} \pm 0.170$ & $41.30^{c} \pm 2.390$ \\
\hline LSD & 4.657 & 1.995 & 2.9250 & 0.1258 & 1.323 \\
\hline
\end{tabular}

- Means, within the same column, followed by the same letter are not significantly different at $<0.05$.

- Means are followed by the corresponding standard deviation

Effect of origanum marjorana powder and their essential oil on serum (MDA) and on erythrocyte (SOD, Catalase, GSH-Px and GSH) levels in experimental rats injected with $\mathrm{Ccl}_{4}$. Table (5) show the activity levels of serum malonaldehyde (MDA) ,enzymatic antioxidants, SOD, Catalase, GSH-Px and non-enzymatic antioxidant, GSH in erythrocyte, respectively, in normal and experimental rat groups. MDA, SOD, Catalase, GSH-Px and GSH did not induce changes in the rats given powder and their essential oil marjoram than the control (M1) group. These results agree with Baâtour et al., (2012 b). The activities of serum maloaldehyde (MDA) activity was significantly increased .While the activities of enzymatic antioxidants (SOD, Catalase, GSH-Px) and non-enzymatic antioxidant (GSH reduced) were significantly decreased in rats injected with $\mathrm{Ccl}_{4}$ group (control), when compared with the normal group. Supplementation of the experimental rat groups injected with $\mathrm{Ccl}_{4}$ with marjoram powder and their essential oil increased the activities of enzymatic antioxidant, (SOD, Catalase, GSH-Px) and non-enzymatic antioxidant, GSH reduced level (Hamed et al., 2012). Hepatic injury induced by $\mathrm{Ccl} 4$ was associated with oxidative stress due to $\mathrm{CCl} 4$-induced free radical production and toxic. Park et al., (2010). Oxidative stress plays an important role in chronic complications of rats injected with $\mathrm{Ccl}_{4}$ and is postulated to be associated with increased lipid peroxidation (Kalava and Menon, 2012). The cytotoxic action of injection with $\mathrm{Ccl}_{4}$ is associated with the generation of reactive oxygen species causing oxidative damage (Azlina et al., 2011).The increased free radicals produced may react with polyunsaturated fatty acids in cell membranes leading to lipid peroxidation. Lipid peroxide-mediated damage has been observed in the development of injected with $\mathrm{Ccl}_{4}$. The increased lipid peroxidation in the serum of rats injected with $\mathrm{Ccl}_{4}$ may be due to the observed remarkable increase in the concentration of free radical in the serum of rats injected with $\mathrm{Ccl}_{4}$. 
Table (5):

Effect of origanum marjorana powder and their essential oil on serum (MDA) and on erythrocyte (SOD, Catalase, GSH-Px and GSH) levels in experimental rats injected with $\mathrm{Ccl}_{4}$.

\begin{tabular}{|c|c|c|c|c|c|}
\hline Treatments & $\begin{array}{l}\text { SOD } \\
(\mathrm{U} / \mathrm{ml})\end{array}$ & $\begin{array}{l}\text { Catales } \\
(\mathrm{U} / \mathrm{ml})\end{array}$ & $\begin{array}{l}\text { GSH-Px } \\
(\mathrm{U} / \mathrm{ml})\end{array}$ & $\begin{array}{c}\text { GSH } \\
(\mathrm{mg} / \mathrm{dl})\end{array}$ & $\begin{array}{c}\text { MDA } \\
(\mathrm{nmol} / \mathrm{ml})\end{array}$ \\
\hline M1(Control normal) & $311.5^{\mathrm{a}} \pm 11.386$ & $141.30^{b} \pm 1.290$ & $172.50^{\mathrm{ab}} \pm 2.240$ & $41.28^{\mathrm{a}} \pm 0.327$ & $12.54^{\mathrm{d}} \pm 2.540$ \\
\hline $\mathrm{M} 2$ (control Ccl 4 ) & $179.2^{\mathrm{d}} \pm 9.220$ & $97.66^{e} \pm 3.66$ & $81.23^{e} \pm 1.120$ & $23.13^{\theta} \pm 1.556$ & $27.29^{a} \pm 2.024$ \\
\hline $\mathrm{M} 3\left(\right.$ Silymarin + $\left.\mathrm{Ccl}_{4}\right)$ & $263.0^{b} \pm 21.981$ & $135.70^{c} \pm 2.72$ & $149.10^{c} \pm 4.110$ & $33.83^{c} \pm 0.764$ & $17.88^{c} \pm 3.361$ \\
\hline $\begin{array}{l}\text { M4 (marjoram essential } \\
\text { oil) }\end{array}$ & $318.7^{a} \pm 18.740$ & $143.30^{a} \pm 3.300$ & $175.20^{\mathrm{a}} \pm 3.240$ & $41.53^{\mathrm{a}} \pm 0.530$ & $11.70^{\mathrm{d}} \pm 0.917$ \\
\hline M5(marjoram powder) & $299.2^{a} \pm 9.160$ & $139.80^{b} \pm 1.840$ & $168.30^{b} \pm 5.330$ & $41.20^{a} \pm 0.200$ & $11.94^{\mathrm{d}} \pm 1.940$ \\
\hline $\begin{array}{l}\text { M6 (marjoram essential } \\
\left.\text { oil }+\mathrm{Ccl}_{4}\right)\end{array}$ & $266.7^{b} \pm 3.680$ & $136.90^{c} \pm 1.920$ & $147.50^{c} \pm 5.510$ & $35.11^{\mathrm{b}} \pm 1.110$ & $15.44^{c} \pm 0.440$ \\
\hline $\begin{array}{l}\text { M7 (marjoram powder }+ \\
\mathrm{Ccl}_{4} \text { ) }\end{array}$ & $239.2^{c} \pm 4.230$ & $132.2^{\mathrm{d}} \pm 2.200$ & $126.20^{\mathrm{d}} \pm 3.180$ & $32.40^{d} \pm 0.361$ & $21.26^{b} \pm 1.260$ \\
\hline LSD & 20.27 & 1.508 & 4.295 & 1.070 & 2.698 \\
\hline
\end{tabular}

- Means, within the same column, followed by the same letter are not significantly different at $<0.05$.

- Means are followed by the corresponding standard deviation.

In the current study, level of serum MDA in rats injected with $\mathrm{Ccl}_{4}$ supplemented with marjoram showed a significant reduction which indicates a decreased rate of lipid peroxidation Baâtour et al., (2012 b) and Al-Harbi,(2011). In general, superoxide dismutase (SOD) is an important antioxidant enzyme which catalyzes the conversion of toxic superoxide radical to less reactive hydrogen peroxide (Kim et al., 2011).SOD is known to be reduced markedly in Ccl4 induced hepatic injury (Ahn et al., 2007). While oxidative stress could be ameliorated via the elevation of hepatic SOD level (Hamed et al., 2012). In addition, glutathione peroxidase (GSH-Px) is another antioxidant enzyme commonly used to investigate the oxidative stress (Fernandez-Sanchez et al., 2011). It has been indicated that antioxidant-like compounds produce hepatic protection through an increase in GSH-Px to scavenge the free radicals (Chen et al., 2011).

Figure (1) showed the microscopic estimation of the liver of the tested rat groups. Control (M1), untreated rat group revealed a normal histological structure of hepatic lobule (Slide 1). Meanwhile, liver of rat from group injected with $\mathrm{Ccl}_{4}$ group (M2) showed congestion of hepatic simusoidal and cytoplasmic vacuolization of hepatocytes (Slide 2). However, liver of rat from group silymarin (drug) showed congestion of central vein and granularity of the cytoplasm of hepatocytes (Slide 3) Tsai et al ., (2008).Meanwhile, liver of rat from group (M7) showed slight dilatation of hepatic sinusoids slight vacuolization of hepatocytes (Slide 4). In addition, liver of rat from groups (M4, M5 and M6) showed no changes with apparent normal hepatocytes (Slide 1). In addition, Figure (1) showed the microscopic estimation of the kidney of the tested rat groups. Control, untreated rat group revealed a normal histological structure (Slide 1). Meanwhile, kidney of rat from group injected with $\mathrm{Ccl}_{4}$ group (M2) showed vacuolation of epithelial lining renal tubules, dilatation and congestion of renal blood vessels associated with hypertrophy of glomerular tufts (Slide 2) JarmilloJuarez, (2008). However, kidney of rat from group silymarin (drug) showed granularity of epithelial lining renal tubules as well as atrophy of some glomerular tufts (Slide 3) Venkatanarayana et al ., (2012).Meanwhile, kidney of rat from group (M7) showed revealed vacuolations of epithelial lining renal tubules (Slide 4).While, kidney of rat from groups (M4, M5 and M6) showed no changes with apparent normal kidney (Slide 1).

Figure (2) showed the microscopic estimation of the heart of the tested rat groups.Control untreated rat group showed apparent normal cardiac muscle fibers with no histopathological changes (Slide 1). Meanwhile, heart of rat from 
group injected with $\mathrm{CCl}_{4}$ (M2) showed vacuolation of some cardiac muscles fibers and granularity of other muscle fibers (Slide 2). However, heart of rat from group silymarin (drug) showed zenker's necrosis of sporadic muscle fibers (Slides 3). Meanwhile, heart of rat from group (M7) showed no changes except vacuolations of sporadic cardiac muscles fibers (Slide 4). While, heart of rat from all groups marjoram (M4, M5 and M6) showed no changes with apparent normal heart (Slide 1). In addition, Figure (2) showed the microscopic estimation of the spleen of the tested rat groups. Control (M1), untreated rat group revealed a normal lymphoid follicles (Slide 1). Meanwhile, spleen of rat from group injected with $\mathrm{Ccl}_{4}$ group(M2) showed lymphocytic necrosis and depletion (Slide 2). However, spleen of rat from group silymarin (drug) showed slight lymphocytic depletion (Slide3). Meanwhile, spleen of rat from all groups marjoram (M4, M5 M6 and M7) showed no changes with apparent normal spleen (Slide 4).

In conclusion; the concentration of lipid peroxidation is a successful indicator to the increment of free radicals in the injected rats with $\mathrm{Ccl}_{4}$. Consequently, administration of marjoram powder and their essential oil significantly declined the levels of lipid peroxidation and thus prevent tissue damage. 
Egypt. J. of Nutrition and Health Vol. 7 No. 1 (2012)

\begin{tabular}{|c|c|}
\hline Liver & Kidney \\
\hline 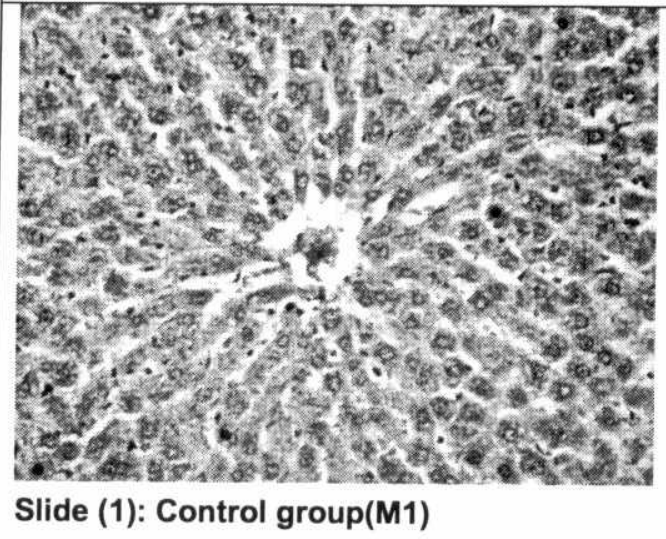 & Slide (1): Control group (M1) \\
\hline 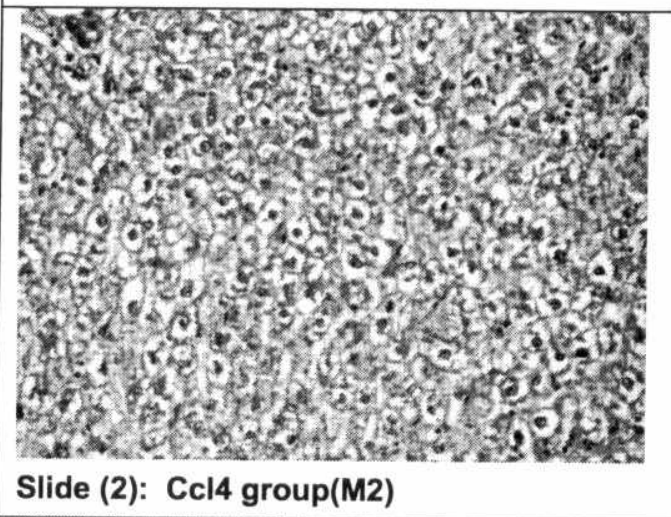 & Slide (2): Ccl4group (M2) \\
\hline 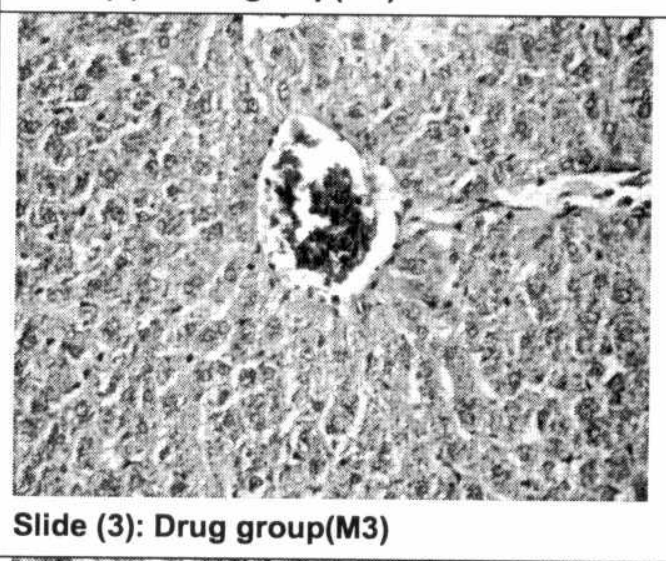 & Slide (3): Drug group (M3) \\
\hline 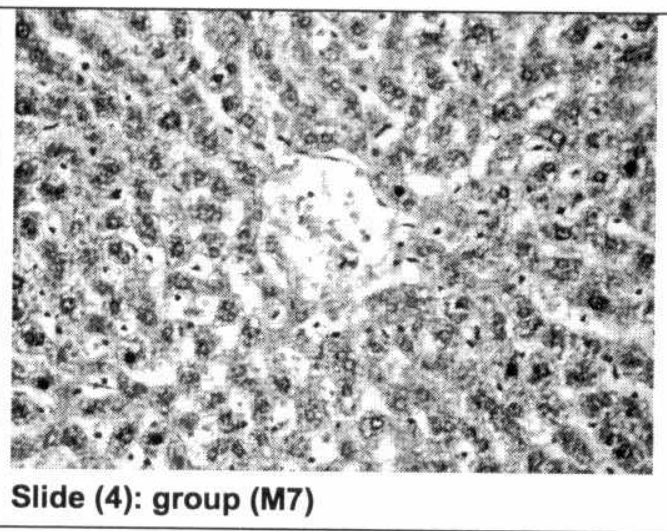 & $\begin{array}{l}2 . \\
\text { Slide (4): group (M7) }\end{array}$ \\
\hline
\end{tabular}


Figure (1): Histopathological changes in liver and kidney sections.

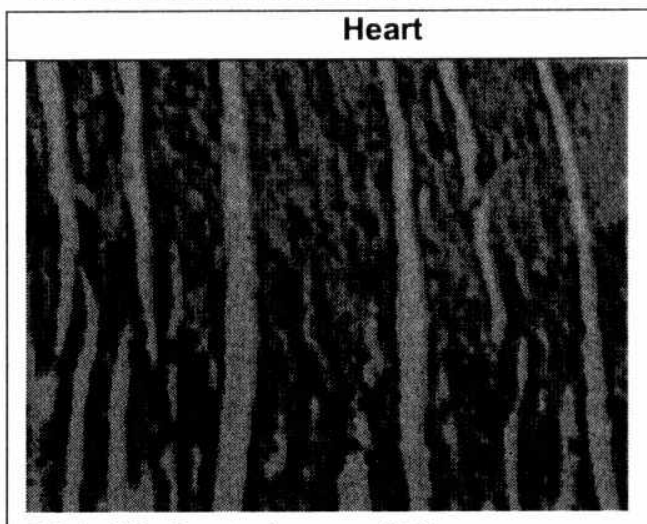

Slide (1): Control group(M1)

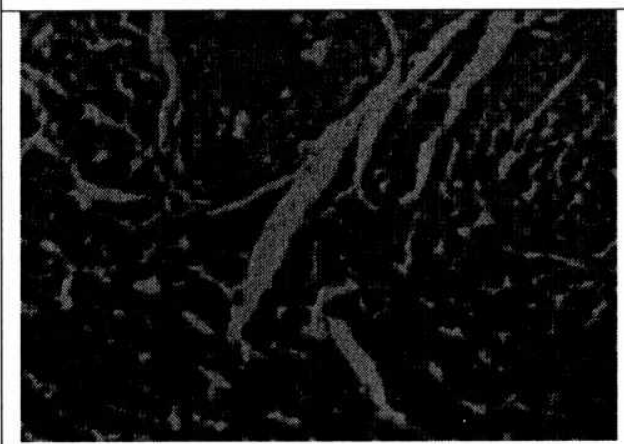

Slide (2): Ccl4 group(M2)

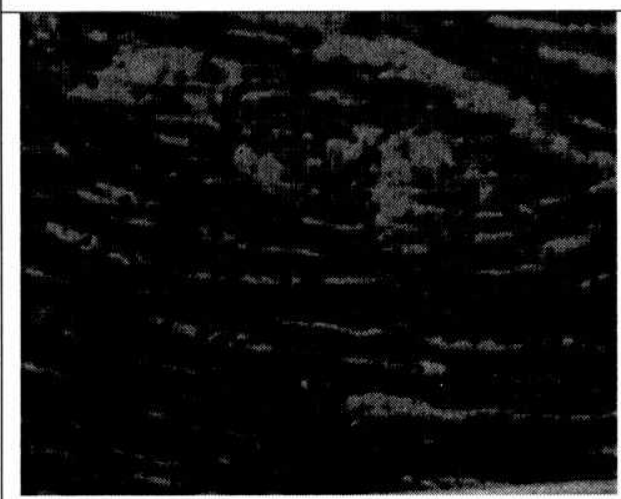

Slide (3): Drug group(M3)

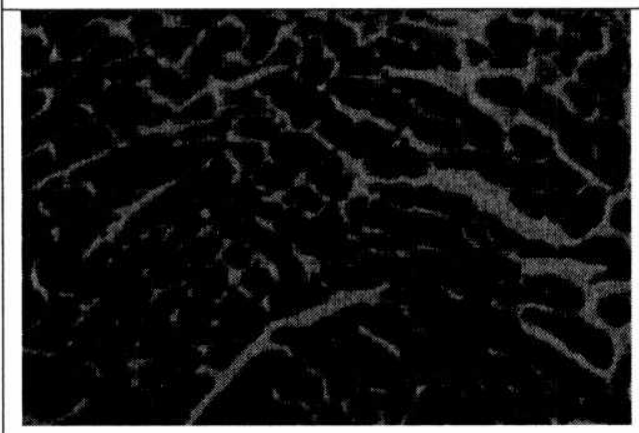

Slide (4): group (M7)

Spleen

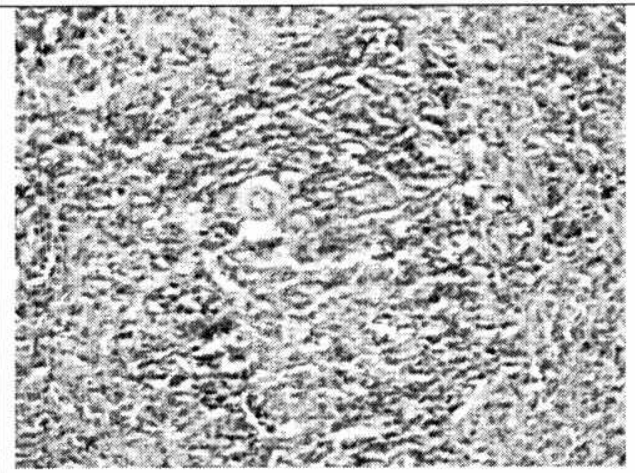

Slide (1): Control group (M1)

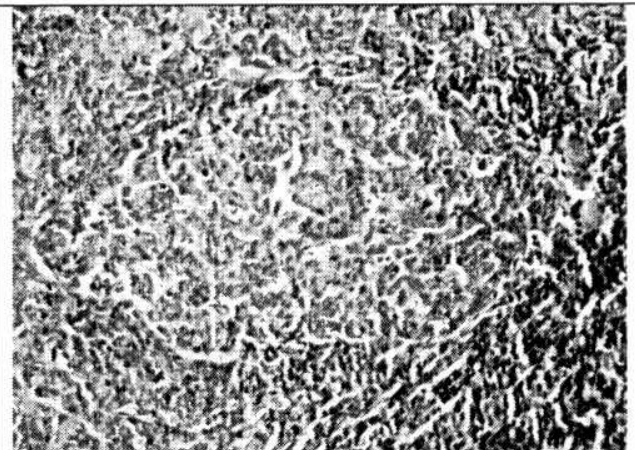

Slide (2): Ccl4 group (M2)

अ50 1.20

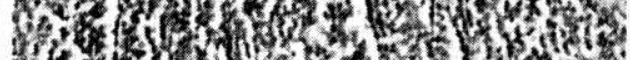

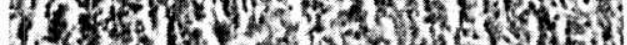
H.

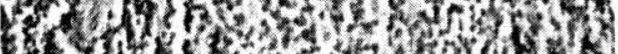

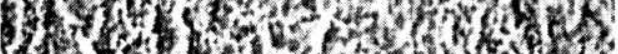

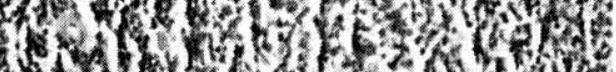

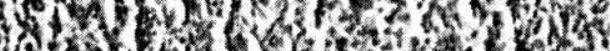
ato

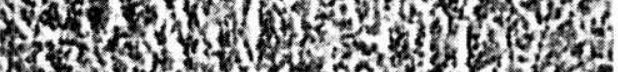

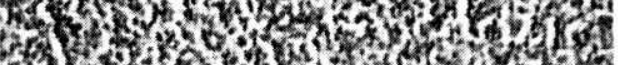
Slide (3): Drug group (M3)

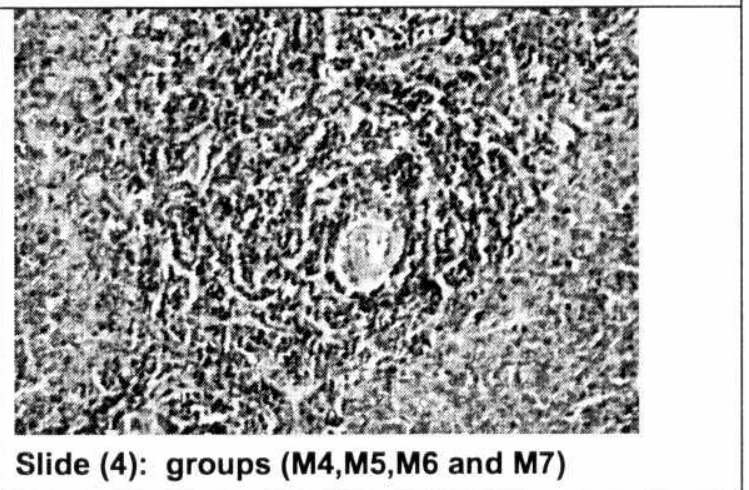

Figure (2): Histopathological changes in heart and spleen sections. 


\section{References}

Abd El-Ghany, M.A. and El-Metwally N.Y., (2010) .

Effect of marjoram leaves on injured liver in experimental rats. Report and Opinion 2(12):181-191.

Aebi ,H.,(1984).

Catalase in vitro. Methods Enzymol .,105:121-136.

Adewole, Stephen, O. ; Abdulkadir A. Salako; Oladepo W.Doherty and Thajasvarie Naicker, (2007).

Effect of melatonin on carbon tetrachloride-induced kidney injury in wistar rats. African Journal of Biomedical Research, Vol. 10: 153 - 164.

Ahn, T. H. ; Yang, Y. S. and Lee, J. C. ,(2007).

"Ameliorative effects of pycnogenol on

carbon tetrachloride-induced hepatic oxidative damage in rats," Phytotherapy Research, vol. 21 (11): 10151019.

Al-Harbi, N. O.,(2011).

Effect of marjoram extract treatment on the cytological and biochemical changes induced by cyclophosphamide in mice. Journal of Medicinal Plants Research ,vol. 5(23): 5479-5485.

Alshawsh, M. A.; Abdulla, M.A.; Ismail, S. and Amin Z.A.,( 2011).

"Hepatoprotective effects of Orthosiphon stamineus extract on thioacetamide-induced liver cirrhosis in rats," Evidence-Based Complementary and Alternative Medicine, vol. 2011:1- 6.

Aneja, R.; Upadhyaya, G.; Prakash, S.; Dass, S. K. and Chandra, R., (2005).

Ameliorating effect of phytoestrogens on $\mathrm{CCl}_{4}$ - induced oxidative stress in the livers of male wistar rats. Artif. Cells Blood Substit. Immobil. Biotechnol., 33(2): 201 - 13.

Ao, Z. H.; Xu, Z.H. ; Lu, Z. M. ; Xu, H. Y.; Zhang, X. M. and Dou, W. F., ( 2009).

"Niuchangchih (Antrodia camphorata) and its potential in treating liver diseases," Journal of Ethnopharmacology, vol. 121( 2) : 194-212.

Assmann, G., (1979).

A fully enzymatic colorimetric determination of HDL-cholesterol in the serum. Internist, 20: 559-565.

Azlina, M. F.N.; Kamisah, Y. ; Rahman, R. F.A. and Faizah, O. , (2011).

Piper Roxb sarmentosum protects lungs against oxidative stress induced by carbon tetrachloride in rats . Journal of Medicinal Plants Research, vol. 5(26): 6128-6135.

Bâatour, O.; Kaddour, R.; Mahmoudi, H.; Tarchoun, I.; Bettaieb, I.;Nasri, N.; Mrah, S.; Hamdaoui, G. ; Lachaâl ,M. and Marzouk, B., (2011).

Salt effects on Origanum majorana fatty acids and essential oils composition. J. Sci. Food. Agr. DOI. 10: $1002-$ 4495. 
Bâatour,O. ; Mahmoudi, H. ; Tarchoun, I. ; Nasri, N.; Trabelsi ,N.; Kaddour, R. ; Zaghdoudi, M.; Hamdaoui, G.; Ksouri, R. ; Lacha, M. and Marzouk, B. ,(2012a).

Salt effect on phenolics and antioxidant activities of Origanum majorana L. shoots. J Sci Food Agric., 93: 134141.

Bâatour, O. ; Nasri, M. B. ; Mahmoud, H. ; Tarchoun, I. ; Nasri, N.; Zaghdoudi, M.; Abidi1,W.; Kaddour, R. ; M'rah, S.; Hamdaoui, G.; Marzouk, B.and Lachaâl, M., (2012 b) .

Salt effect on physiological, biochemical and anatomical structures of two Origanum majorana varieties (Tunisian and Canadian). Afr. J. Biotechnol., Vol. 11(27): 7109-7118.

Bâatour, O. ; Tarchoun, I. ; Mahmoud, H.; Nasri, N.; Abidi1,W.; Kaddour, R.; Hamdaoui, G.; Nasri, M. B.; Lacha, M. and B. Marzouk,(2012 c).

Culture conditions and salt effects on essential oil composition of sweet marjoram (Origanum majorana) from Tunisia. Acta Pharm. 62 (3) :251-261.

Barbosa, L.N.;Rall ,V.L.; Fernandes, A.A.;Ushimaru, P.I.;Da, S.P.I. and Fernandes, A. Jr., (2009).

Essential oils against foodborne pathogens and spoilage bacteria in minced meat. Food borne Pathog. Dis., 6(6): 725-728.

Bergmeyer, H. U. and Harder, M. , (1986).

A colorimeteric method of determination of serum glutamic oxaloacetic and glutamic pyruvic transaminase. Clin. Biochem., 24: 28 - 34.

Brenner, D. A.; Waterboer, T. and Choi , S. K. ,(2000): "New aspects of hepatic fibrosis," Journal of Hepatology, vol. $32,(1): 32-38$.

Campbell , J.A. , (1963).

Methodology of protein evaluation. RAG. Nutr. Document R.101 ads. 37, June Melting, New York.

Chen, Mei-Fen; Chung, Hsien-Hui and Lu, Han-Lin ,(2012).

Protection of the Extracts of Lentinus edodes Mycelia against Carbon-Tetrachloride-Induced Hepatic Injury in Rats. The ScientificWorld Journal,vol. 2012:1- 8.

El-Ashmawy ,I.M.; Amal ,S. and Salama, O.M. (2007):

Acute and long term safety evaluation of Origanum majorana essential oil. Alex. J. Pharm.Sci., 21: 29- 35.

EL Bushuty, D.H. and Shanshan, N.M., (2012).

Effect of natural herbs of marjoram and ginger on hypercholesterolemic rats. Managing Knowledge and intellectual capital in Higher Education institutions in Egypt and Arab World Faculty of Specific Education Mansoura University. 11-12 April, 1755-1767.

Ellman, G.L. , (1959).

Tissue sulfhydrl groups. Archieves of Biochem. and Biophys., 82: 70-77.

Fawcett, J. K. and Scott, J. E. ,(1960).

Enzymatic colorimetric method for determination of urea in serum, plasma and urine. J. Clin. Path., 13,156-162. 
Fernandez-Sanchez, A.; Madrigal-Santillan, E.and Bautista, M., (2011) .

"Inflammation, oxidative stress, and obesity," International Journal of Molecular Sciences, vol. 12, ( 5) : 31173132.

Fossati, P. and Prencipe, L., (1982):

The determination of triglycerdes using enzymatic methods. Clin. Chem., 28: 2077 - 2081

Freire, J.M.; Cardoso, M.G.; Batista, L.R. and Andrade, M.A.,(2011).

Essential oil of Origanum majorana L., Illicium verum Hook. f. and Cinnamomum zeylanicum Blume: chemical and antimicrobial characterization. Rev.Bras.de Plantas Med.,vol.13(2):209-214, ISSN 1516 - 0572.

Guenther, M. ,(1961).

"The essential oils."Vol. III, IV, 4th Ed..D. Van Nostrand Company, Inc. Princeton, New Jersy. Tornto, New York, London.

Hamed, M. A.; Ali, S. A. and Saba El-Rigal, N., (2012).

Therapeutic Potential of Ginger against Renal Injury Induced by Carbon Tetrachloride in Rats. The Scientific World Journal, vol. 2012:1-12.

Hegsted, D.M. ; Mills, R.C. ; Elvehjem, C.A. and Hart, E.B., (1941).

Choline in the nutrition of check. J. Biol. Chem., 138: 459.

Henry, R. J. , (1974).

Clinical Chemistry, Principles and Technichs, $2^{\text {nd }}$ Edition, Harper and Raw, p. 525.

Jaramillo - Juarez ,F.; Rodriguez - Vazquez , M.L.; Rincon Sanchez , A.R.; Martine z, M . C ; Ortiz,G.G.;Liamas,J.;Posadas,F.A. and Reyes,J.L.,(2008).

Acute renal failure induced by carbon tetrachloride in rats with hepatic cirrhosis. Annals of Hepatology,7,(4):331338.

Kalava, S.V. and Menon, S.G. , (2012).

Protective efficacy of the extract of volvariella volvacea (bulliard exfries) singer against carbon tetra chloride induced hepatic injury. IJPSR, vol. 3(8): 2849-2856.

Kim, B. M. ; Rhee, J. S. ; Park, G. S. ; Lee, J. ; Lee, Y.M. and Lee, J. S. (2011).

"Cu/Zn- and Mn-superoxide dismutase (SOD) from the copepod Tigriopus japonicus: molecular cloning and expression in response to environmental pollutants," Chemosphere, vol. 84,(10): 1467-1475.

Lane Peter, W. and Person, A.E.G. (1971):

Dietary Requirements in the Laboratory: Animal Principles and Practice, Acad. Press, London and New York. p142.

Lee, H. S.; Keum, K. Y. and Ku, S. K., (2007).

Effects of picrorrhiza rhizome water extracts on the subacute liver damages induced by carbon tetrachloride. J. Med. Food, 10(1): $110-117$. 
Lis, A.; Piter, S. and Góra, J., (2007).

A comparative study on the content and chemical composition of essential oils in commercial aromatic seasonings Herba Polonica, vol.53 (1):21-26.

Meltzer, H.M. ; Folmer, M.; Wang, S. ; Lie, Q. ; Maage, A. and Mundal, H.H., (1997).

Supplementary selenium influences the response to fatty acid induced oxidative stress in humans. Biological Trace Element Research, 60: 51-67.

Nishikimi ,M.; Roa,N.A. and Yog,K., (1972).

The occurrence of superoxide anion in the reaction of reduced phenazine methosulphate and molecular oxygen. Biochem.Bioph. Res. Common., 46: 849-854.

Ozturk, M.; Akdogan, M.; Keskin, I.; Kisioglu, A.N.; Oztas, S. and Yildiz, K., (2012).

Effect of silybum marianum on acute hepatic damage caused by carbon tetrachloride in rats.Biomedical Research , 23 (2): 268-274.

Park, C.M. ; Cha, Y. S. ; Youn, H. J. ; Cho, C.W. and Song, Y. S. ( 2010).

"Amelioration of oxidative stress by dandelion extract through CYP2E1 suppression against acute liver injury induced by carbon tetrachloride in sprague-dawley rats," Phytotherapy Research, vol. 24, (9): 1347-1353.

Rotruck. J.J.; Pope, A. L.; Ganther, H.E. and Swanson, A.B. , (1973).

Selenium: biochemical role as a component of glutathione peroxidase. Science, 179: 588-590.

Roy, C.K.; Kamath, J.V.and Asad, M.,( 2006).

Hepatoprotective activity of Psidium guajava Linn. leaf extract. Indian J Exp Biol.,44:305-311.

Saleem, M., S. Madhusudhana Chetty, S. Ramkanth, V. S. T. Rajan, K. Mahesh Kumar, and K. Gauthaman, (2010). "Hepatoprotective herbs-a review," International Journal of Research in Pharmaceutical Sciences, vol. 1, ( 1$): 1-5$.

Snedecor, G.W. and Cochran, W.G. (1980).

Statistical methods. $7^{\text {th Ed., }}$ p. 420. lowa Stat. Univ. Press, Ames, lowa, USA.

Stickel, F. and Schuppan, D., (2007).

"Herbalmedicine in the treatment of liver diseases," Digestive and Liver Disease, vol. 39, (4): 293-304 .

Trinder, P. , (1969).

Determination of glucose in blood using glucose oxidase with an alternative oxygen acceptor. Am. Clin. Biochem., 6:24-27.

Tsai, J. H. ; Liu, J. Y. ; Wu, T. T. ; Ho, P. C. ; Huang, C. Y. ; Shyu, J. C. ; Hsieh, Y. S. ; Tsai, C. C. and Liu, Y. C.,(2008).

Effects of silymarin on the resolution of liver fibrosis induced by carbon tetrachloride in rats. Journal of Viral Hepatitis, 15: 508-514.

Wallach, J., (1992).

Interpretation of Diagnostic Tests. A synopsis of laboratory medicine, $5^{\text {th Ed }}$. A little brown hand- book, Boston. 
Waston, D.A., (1960).

Simple method for the determination of serum cholesterol. Clin. Chem. Acta., 5:589-596.

Wieland, H. and Seidel, D. , (1983).

A fully enzymatic colorimetric determination of HDL-cholesterol in the serum. J. Nutr., 109: 760 - 766.

Wong, B. H. ; Zuzel, K. A. ; Rahman, K. and Billington, D. (1998):

Protective effect of aged garlic extract against bromobenzene toxicity to precision cut rat slices. Toxicology., 126(3): 213-222.

Varley, H. ; Gewenlock, A. and Bell, M., (1980).

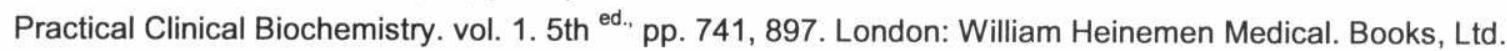

Venkatanarayana, G. ; G. Sudhakara, P.; Sivajyothi, Pala, Indira ,(2012) .

Protective effects of curcumin and vitamine on carbon tetra chloride-induced nephrotoxicity in rats. EXCLI Journal,11: 641 - 650 - ISSN $1611-2156$.

Yoon, B.I.; Choi, Y.K. ; Kim, D.Y.; Hyun, B.H.; Joo, K.H.; Rim, H.J. and Lee, J.H. (2001).

Infectivity and pathological changes in murine clonorchiasis: Comparison in immunocompetent and immunodeficient mice. J. Vet. Med. Sci., 63(4): 421-425. 


\section{التأثير الوقائي للبردقوش على جها الأكسدة في الفئران المصابة برابع كلوريد الكربون}

\section{نجلاء حسانين محمد حسانين}

قسم الأغذية الخاصة والتغذية ـ معهد بحوث تكنولوجيا الأغذية ـ مركز البحوث الزراعية ـ الجيزة - جمهورية مصر العربية

\section{الملخص العربي}

إصابة الكبد الناجمة عن الفيروسات والمواد الكيميانية السامة، وبعض الأدوية والملوثات البينية، في ازدياد على مدى العقود

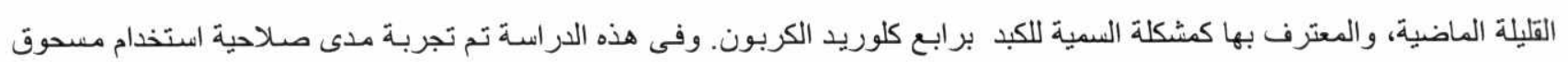

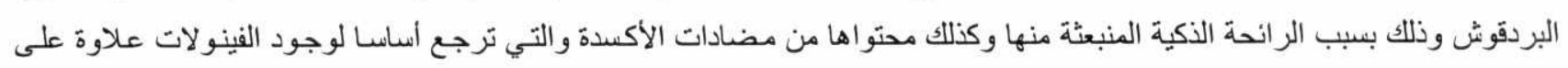

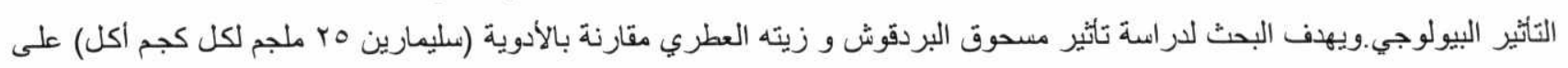

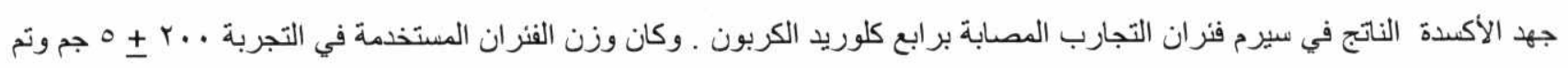

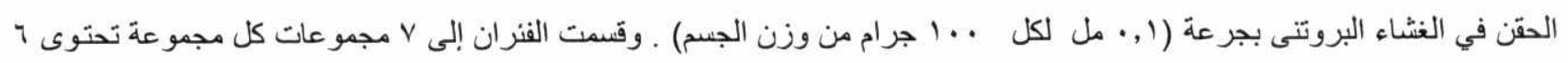

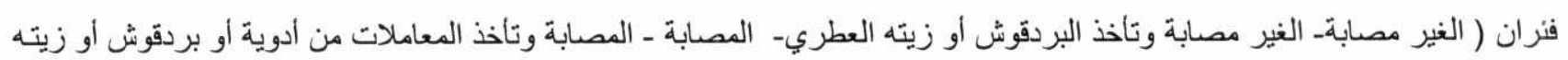

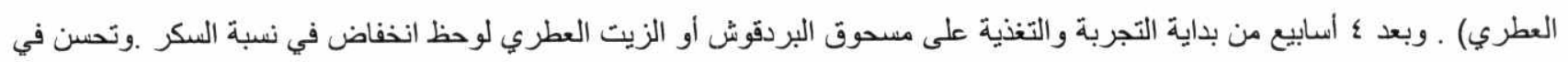

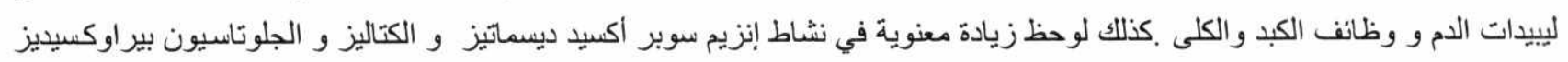

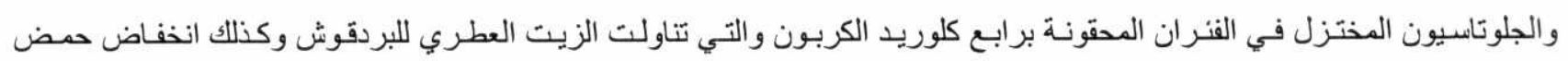

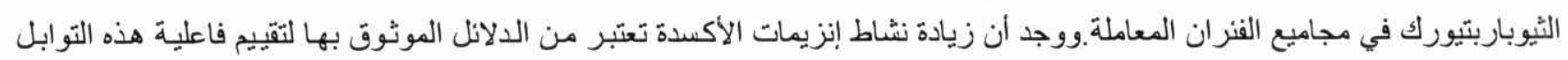

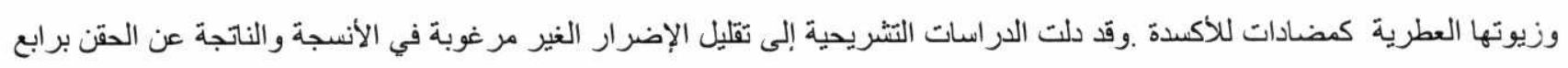

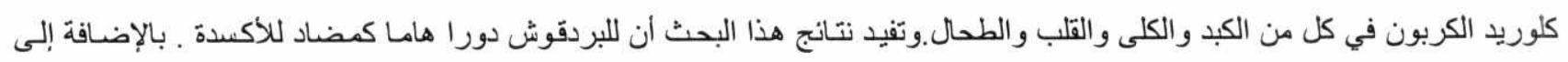

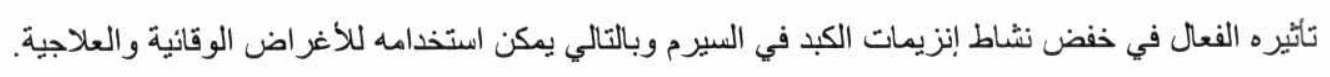

